\title{
Captures and Diet of Three Sharks Species in the Veracruz Reef System
}

\author{
José Otilio Avendaño-Alvarez, Horacio Pérez-España, David Salas-Monreal, \\ Emiliano García-Rodríguez \\ Institute of Marine Science and Fisheries, Veracruz University, Veracruz, Mexico \\ Email: ottoavend@gmail.com
}

Received January 15, 2013; revised March 12, 2013; accepted March 26, 2013

Copyright (C) 2013 José Otilio Avendaño-Alvarez et al. This is an open access article distributed under the Creative Commons Attribution License, which permits unrestricted use, distribution, and reproduction in any medium, provided the original work is properly cited.

\begin{abstract}
During July to November of 2008, the artisanal fisheries captured juvenile sharks belonging to the Carcharhinus and Sphyrnidae family in the Veracruz Reef System (south western Gulf of Mexico). The three most abundant organisms were of the species Sphyrna lewini, Carcharhinus brevipinna and Rhizoprionodon terraenovae. Local fisherman recognized five captured areas of sharks as a direct way or bycatch. Some of these areas are located near to eddies formations and river discharges (high productivity areas). These top predators fed on benthic and demersal prey of coastal and reef habits had been the Teleost group the most important item in its diet. However it is possible to observe differences in its feeding tendency.
\end{abstract}

Keywords: Captures; Diet; Sharks; Veracruz

\section{Introduction}

The Veracruz Reef System (VRS) is located in the south western Gulf of Mexico in front of the Port of Veracruz, Boca del Rio village and the fishery town of Anton Lizardo (Figure 1), which bases their economy in a multi specific artisanal fishery, which employs different fishing gears [1]. The VRS is a reef complex which is constituted by 23 corallines structures which support a high biodiversity considered a natural protected area since $1992[2,3]$.

The elasmobranchs fisheries are not regulated and its records are incomplete or generalized [4]. The artisanal fisheries in the Gulf of Mexico focused on sharks, capture mostly from the Carcharhiniformes species, specifically the Carcharhinidae and Sphyrnidae families. The most important economical species are: Rhizoprionodon terraenovae, Carcharhinus acronotus, Squalus cubensis, Sphyrna tiburo, Carcharhinus limbatus, Sphyrna lewini, Carcharhinus leucas, Carcharhinus falciformis and Carcharhinus porosus, the Carcharhinus brevipinna specie is the fifth specie in number of capture, therefore it is considered of low economic value [1].

In May of 2007 it was decreed the NOM-029-PESC2006 to establish a statistic record of shark fisheries [5], however in the southwestern Gulf of Mexico the artisanal fisheries catch shark without species records [1]. The only knowledge is that the most abundant species in the area is the Rhizoprionodon terraenovae, but its records are mostly generalized with another juvenile organism of different species [1].

In the last twenty years the captures of sharks have increased around the world [6,7], this increase is due to the interest in their fins and meat, but also to the increase by bycatch in many fisheries [8]. In general, the existent populations of sharks have been considered threatened or endangered, due to their particular vulnerability under fisheries pressure and to its cycle live (e.g. low fecundity and slow sexual maturity) $[9,10]$, which prevents them from recovering their populations levels [11].

Because they play the role of a top predator in the marine ecosystems, many shark species are considered as key species [12-14]. In 1994 the Convention of the International Trade of Endangered Species (CITES) issued a resolution requesting to the United Nations for Food and Agriculture Organization (FAO) to collect and organize the necessary information regarding the biological and commerce aspects of the shark populations [15,16], because, despite the ecological researches, the conesquences of remove top predators in the ocean continue to be uncertain $[8,17]$. 


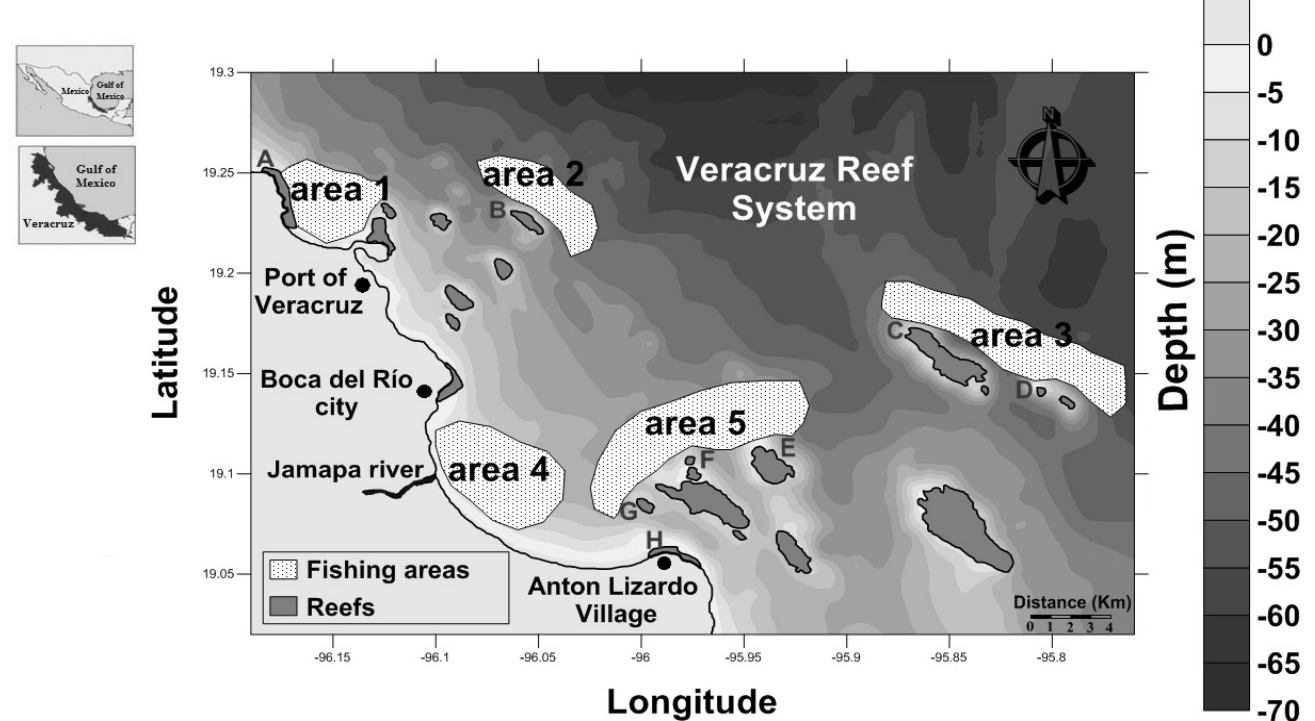

Figure 1. Study area and capture areas of sharks into the Veracruz Reef System, (A) Punta Gorda reef, (B) Anegada de Adentro reef, (C) Anegada de Afuera reef, (D) Satiaguillo reef, (E) Enmedio reef, (F) Polo reef, (G) Blanca reef and (H) Giote reef.

The information obtained from the analysis of stomach contains contributes with necessary information to understand the ecological role of the predators in the ecosystem $[16,18,19]$, showing the feeding behavior and possible relationship between sympatric species $[13,20$ 22]. Therefore, in order to understand the feeding and relationships of top predators a study of the stomach contains and the area of capture were performed in the VRS.

\section{Materials and Methods}

A sampling of captured sharks by the artisanal fleet of Anton Lizardo, townships of Alvarado and Veracruz City, were analyzed from the 9th of July to November 14, 2008 in order to determine the reproductive stage of sharks, the Total Length (TL cm), the Pre-Caudal Length (PCL cm) were sampled, and the sex of each organism and were compared with previous research of age and growth [23-25].

For the stomach content analysis, gut content of each organism were transported to the laboratory in labeled plastic bags into a refrigerated container. Samples were frozen at $-2^{\circ} \mathrm{C}$ for further analysis. For the analysis, each stomach was dissected to separate the stomach contents, each food item was described at the lower taxonomic level, and the trophic spectrum was analyzed and quantifying through the rates of numerical abundance percentage $(\% \mathrm{~N})$, weight of abundance percent $(\% \mathrm{~W})$ and the percentage of frequency of occurrence $(\% \mathrm{FO})$.

The $\% \mathrm{~N}$ was calculated by dividing the numbers of items $i$ by the total number of items founded in the diet, the $\% \mathrm{~W}$ was calculated by dividing the weight of the item $i$ by the total weight founded in the diet, and the $\%$ FO was calculated by dividing the total numbers of stomach were the item $i$ was founded by the total of stomach analyzed. The Relative Importance Index (IRI) was calculated [26], in order to obtain the importance of each food group in the diet of the predators in form of percentage [13] as follow:

$$
\% \mathrm{IRI}=[(\% \mathrm{~N}+\% \mathrm{~W}) \times \% \mathrm{FO}] \times 100
$$

In order to obtain the similarities between the diets of sharks, a cluster analysis of similarity was done using the value of \%IRI. The equation of minimum variance or Ward's was used to build the similarity matrix and Bray Curtis distances were used as linkage method. The analysis presents a scale of 0 to 1 , were 0 means $0 \%$ of similitude and one means $100 \%$. To elucidate the alimentary tendency of each predator a PCA (Principal Component Analysis) plot was developed. Both analyses were performed employing the software CAP 3 (Community Analysis Package, 2004).

\section{Results}

A total of 191 sharks were sampled from captures of the artisanal fleet. The three species of sharks obtained were: Sphyrna lewini, Carcharhinus brevipinna and Rhizoprionodon terraenovae.

Of the specie $S$. lewini 35 were obtained, 20 males and 15 females. The Total Length (TL) ranged was of 66 $167 \mathrm{~cm}$, with an average length of $85 \mathrm{~cm}$. This species show a sexual maturity at $170 \mathrm{~cm}$ (TL) for males and 223 $\mathrm{cm}$ (TL) for females [23]. According to this criterion none of the sharks sampled were mature.

A total of 33 sharks of the species C. brevipinna were sampled, 19 males and 14 females. The Total Length (TL) ranged from 71 to $176 \mathrm{~cm}$, with an average of $91 \mathrm{~cm}$. This predator reach the maturity at $220 \mathrm{~cm}$ (TL) for male 
and female [24], therefore none of the sharks studied here were sexually mature.

Finally a total of 123 sharks of $R$. terraenovae specie were sampled, 75 males and 48 females. This shark showed a Total Length (TL) between 50 and $104 \mathrm{~cm}$, with an average of $61 \mathrm{~cm}$. This species reaches its sexual maturity at $60 \mathrm{~cm}$ of PCL for male and female [25]. Therefore only $5.7 \%(n=7)$ organisms were sexually mature.

\subsection{Capture Areas and Fishing Gears}

In the VRS five capture areas (Figure 1) of sharks were identified, and two fishing gears were used in order to capture sharks: bottom longline and gillnet.

Sphyrna lewini was mostly captured using bottom longline with 33 organisms and one was captured with gillnet, however one shark was captured with beach seine in the area 4, these organism was the nearest captured organism to the coast, at less of 300 meters of the coastal line. The beach seine is used by the fishermen only to capture coastal fishes, but they also may capture sharks and juveniles rays. The Carcharhinus brevipinna species was captured using two fishing gears. 29 organisms were captured with bottom longline and four with gillnet. Finally, the Rhizoprionodon terraenovae was captured using two fishing gears, 53 organisms were captured with bottom longline and 70 with gillnet.

The capture area 1 locally named "La Pinera" is located in front of Punta Gorda reef, and according with the fishermen it is one of the principal fishing areas to capture juvenile sharks locally known with the name of "cazon" owing to the market price they have. This area is an ideal area for sharks owing to the discharges of residual water in the middle part of the bay and to the swell system, which increase the local productivity, making this area an ideal place for feeding.

The capture area 2 named "Anegada de Adentro" is located at the external area of the Anegada de Adentro reef. This is a deeper area located close to a cyclonic eddy (Figure 2) [27].

The capture area 3 named "La Cordillera" is located in the exposed side of Anegada de Afuera and Satiaguillo reefs. It is one of the deepest and less human impacted areas owing to the distance from coast. In this area the fishermen use bottom longline to capture sharks in a directed way, which has relation to the anticyclone eddy formed in the same area (Figure 2) generating a feed bottom zone.

The capture area 4 named "La Guada" is located in the coastal area in front of the Jamapa River and close to the cyclonic eddy [27]. Those two characteristics make this place and ideal area for feeding. Further, butcheries located at the entrance of the river (Arrollo Moreno) use to through parts of dead animals (beef, pork and chicken)

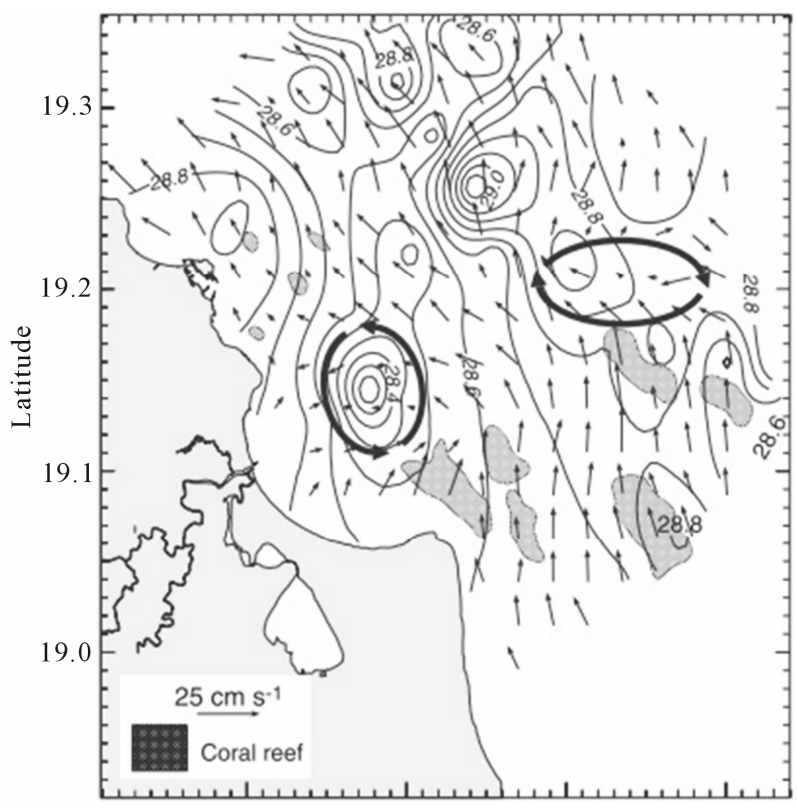

Figure 2. Surface water velocity $(1 \mathrm{~m}$ depth) and residual sea surface temperature and the coral reefs are shown in light-gray color. The dark circular arrows represent the eddies. Obtained from Salas-Monreal et al. (2009), to observer the formation zones of eddies in the VRS.

with no commercial value to the river.

The captured area 5 named "Enmedio" is located in the northernmost part of Enmedio, Polo, Blanca and Giote reefs, and is a high productive area owing to the cyclonic eddy. Also on the capture areas 3,4 and 5, the local fishermen capture sharks in a directly way using bottom longline and gillnet. They use the leeward area of the reef slope of the areas 4 and 5 to place their fishing gear since they are transit areas to sharks from the open ocean towards the feeding areas between the reefs.

The cyclonic eddy is located between the capture areas 2, 4 and 5, and its vertical water movement resuspended nutrients from the bottom, making this a high productivity area. All captured areas are located near an eddy or near the river discharges.

\subsection{Analysis of Stomach Contents}

All sharks captured were juvenile organisms. Twelve of the 35 organisms of the S. lewini had at least one prey in their stomach. The analysis of the stomach contains obtained for this species resulted on a total of 13 food items of eight different families, eight generous and eight species. The trophic spectrum was composed of two groups. The dominant group was the Teleost with $69 \% \mathrm{~N}$, followed by the Crustacean with the $31 \% \mathrm{~N}$. According to the IRI the prey Litopenaeus setiferus was the most important item in its diet with $34.6 \%$, followed by Paralichthys sp. with $33.7 \%$ and Epinephelus adscensionis with $14.5 \%$ (Table 1). These preys are benthic organisms, 
and the demersal preys have a lower value of relative importance.

Of the total C. brevipinna captured, 14 had at less one prey in its stomach. The analysis of the stomach contents was performed with a total of 21 food items belonging to 12 families, 13 generous and 13 species. The trophic spectrum was composed by two groups. The dominant group was the Teleost with $95.2 \% \mathrm{~N}$, and the other group was the Cephalopods with $4.8 \% \mathrm{~N}$. The IRI showed that the most important item in its diet was the Brevoortia gunteri with $37.9 \%$, Mugil curema with $17.2 \%$, and Scomberomorus maculatus with $14.3 \%$ (Table 2). This teleost fishes have demersal behavior, as well as the rest of its items prey, C. brevipinna also feed on benthic preys in a smaller proportion, like Gymnothorax funebris and Octopus vulgaris both with $3.3 \%$ of IRI.

Of the total $R$. terraenovae captured, 25 had at least one prey in its stomach. The analysis of stomach contents performed with a total of 28 food items showed eleven families, eleven generous and eleven species. In this case the trophic spectrum was composed by three groups being the dominant group the Teleost with $78.6 \% \mathrm{~N}$, followed by the Crustaceous and Cephalopods both with the $10.7 \% \mathrm{~N}$. The index of relative importance showed that Haemulon aurolineatum was the most important item in the diet of this predator with $72.9 \%$, followed by Scombreromorus maculatus with $15.9 \%$ (Table 3). Despite the number of items prey in the diet of this predator it is clear a tendency of the feeding behavior on Teleost, counting with an opportunistic behavior on benthic spe- cies like Calappa ocellata and Octopus vulgaris with $1.6 \%$ of IRI.

\subsection{Analysis of Diet Similarities}

Using a cluster analysis of similarity (Figure 3(a)) it was possible to determine that between the species C. brevipinna and $R$. terraenovae, there is a medium level of similarity of the food spectrum with $43.7 \%$, but they are more similar than for the $S$. lewini specie, since it differ from the other two species by a $81.5 \%$ of its food spectrum. The three predators feed on benthic and demersal preys, with coastal and reef habits. In the PCA analysis it is possible to observe that the prey correlation (Figure 3(b)). Gymnothorax funebris is the prey with more relation between S. lewini and the other two predators. C. brevipinna and $R$. terraenovae have more similarities and are more correlated to teleosts Anchoa hepsetus, Scomberomorus maculatus and Selene vomer.

The results of Index of Relative Importance, cluster and the PCA, could be indicating a lower level of feeding competence due to the high availability of items prey.

\section{Discussions}

The specie Sphyrna lewini have coastal behavior and are observed sporadically on the bays, with segregation by age groups, the juveniles are mostly found near the coast during its development stage. The sharks Carcharhinus brevipinna and Rhizoprionodon terraenovae are species with coastal habits (shallow waters). They live on the coastal

Table 1. Diet composition of Sphyrna lewini $(\mathrm{N}=12$, size range from 66 to $81 \mathrm{~cm}$ of $\mathrm{TL})$, in numerical percentage (\%N), percentage of weight abundance $(\% \mathrm{~W})$, percentage of frequency of occurrence $(\% \mathrm{FO})$ and index of relative importance (\%IRI).

\begin{tabular}{|c|c|c|c|c|c|c|c|}
\hline Groups & Family & Prey & $\mathrm{N}$ & $\% \mathrm{~N}$ & $\% \mathrm{FO}$ & $\% \mathrm{~W}$ & $\%$ IRI \\
\hline \multicolumn{8}{|l|}{ Teleosts } \\
\hline & Paralichthyidae & Paralichthys sp. & 2 & 15 & 17 & 52 & 33.7 \\
\hline & Serranidae & Epinephelus adscensionis & 2 & 15 & 17 & 13.7 & 14.5 \\
\hline & Muraenidae & Gymnothorax funebris & 1 & 8 & 8 & 14.3 & 5.5 \\
\hline & Triglidae & Prionotus sp. & 1 & 8 & 8 & 11 & 4.7 \\
\hline & Carangidae & Caranx hippos & 1 & 8 & 8 & 2.2 & 2.5 \\
\hline & Haemulidae & Haemulon aurolineatum & 1 & 8 & 8 & 1.9 & 2.4 \\
\hline & Mugilidae & Mugil curema & 1 & 8 & 8 & 0.9 & 2.1 \\
\hline & & Total Teleosts & 9 & 69 & 75 & 96 & 65 \\
\hline \multicolumn{8}{|c|}{ Crustaceous } \\
\hline & Penaeidae & & & & & & \\
\hline & & Litopenaeus setiferus & 4 & 31 & 33 & 4 & 34.6 \\
\hline & & Total Crustaceous & 4 & 31 & 33 & 4 & 34.6 \\
\hline
\end{tabular}


Table 2. Diet composition of carcharhinus brevipinna ( $N=14$, size range from 75 to $176 \mathrm{~cm}$ of $\mathrm{TL}$ ), in numerical percentage $(\% \mathrm{~N})$, percentage of weight abundance $(\% \mathrm{~W})$, percentage of frequency of occurrence $(\% \mathrm{FO})$ and index of relative importance (\%IRI).

\begin{tabular}{|c|c|c|c|c|c|c|c|}
\hline Groups & Family & Prey & $\mathrm{N}$ & $\% \mathrm{~N}$ & $\% \mathrm{FO}$ & $\% \mathrm{~W}$ & $\%$ IRI \\
\hline \multicolumn{8}{|l|}{ Teleost } \\
\hline & Clupeidae & Brevoortia gunteri & 6 & 28.6 & 21.4 & 17.9 & 37.9 \\
\hline & Mugilidae & Mugil curema & 2 & 9.5 & 14.3 & 22.1 & 17.2 \\
\hline & Scombridae & Scomberomorus maculatus & 2 & 9.5 & 14.3 & 16.8 & 14.3 \\
\hline & Haemulidae & Haemulon aurolineatum & 2 & 9.5 & 14.3 & 7.5 & 9.2 \\
\hline & Muraenidae & Gymnothorax funebris & 1 & 4.8 & 7.1 & 7.4 & 3.3 \\
\hline & Carangidae & Cholorcombrus chrysurus & 1 & 4.8 & 7.1 & 5.4 & 2.8 \\
\hline & Carangidae & Selene vomer & 1 & 4.8 & 7.1 & 4.5 & 2.5 \\
\hline & Synodontidae & Synodus sp. & 1 & 4.8 & 7.1 & 3.6 & 2.3 \\
\hline & Paralichthydae & Paralichthys sp. & 1 & 4.8 & 7.1 & 3.4 & 2.2 \\
\hline & Sphyraenidae & Sphyraena sp. & 1 & 4.8 & 7.1 & 2.2 & 1.9 \\
\hline & Engraulidae & Anchoa hepsetus & 1 & 4.8 & 7.1 & 0.9 & 1.5 \\
\hline & Exocoetidae & Hirundichthys speculiger & 1 & 4.8 & 7.1 & 0.8 & 1.5 \\
\hline & & Total Teleosts & 20 & 95.2 & 121.4 & 92.5 & 96.7 \\
\hline \multicolumn{8}{|c|}{ Cephalopods } \\
\hline & Octopidae & Octopus vulgaris & 1 & 4.8 & 7.1 & 7.5 & 3.3 \\
\hline & & Total Cephalopods & 1 & 4.8 & 7.1 & 7.5 & 3.3 \\
\hline
\end{tabular}

Table 3. Diet composition of Rhizoprionodon terraenovae ( $N=25$, size range from 53 to $90 \mathrm{~cm}$ of $\mathrm{TL}$ ), in numerical percentage $(\% \mathrm{~N})$, percentage of weight abundance $(\% \mathrm{~W})$, percentage of frequency of occurrence $(\% \mathrm{FO})$ and index of relative importance (\%IRI).

\begin{tabular}{|c|c|c|c|c|c|c|c|}
\hline Groups & Family & Prey & $\mathrm{N}$ & $\% \mathrm{~N}$ & $\% \mathrm{FO}$ & $\% \mathrm{~W}$ & $\%$ IRI \\
\hline \multicolumn{8}{|l|}{ Teleosts } \\
\hline & Haemulidae & Haemulon aurolineatum & 10 & 35.7 & 40 & 34.3 & 72.9 \\
\hline & Scombridae & Scomberomorus maculatus & 3 & 10.7 & 12 & 40.0 & 15.9 \\
\hline & Engraulidae & Anchoa hepsetus & 3 & 10.7 & 8 & 2 & 2.6 \\
\hline & Elopidae & Elops saurus & 1 & 3.6 & 4 & 11.2 & 1.5 \\
\hline & Muraenidae & Gymnothorax funebris & 3 & 10.7 & 4 & 1.6 & 1.3 \\
\hline & Carangidae & Selene vomer & 1 & 3.6 & 4 & 7.3 & 1.1 \\
\hline & Paralichthyidae & Paralichthys sp. & 1 & 3.6 & 4 & 0.4 & 0.4 \\
\hline & & Total Teleosts & 22 & 78.6 & 76 & 96.6 & 95.8 \\
\hline \multicolumn{8}{|c|}{ Crustaceous } \\
\hline & Calappidae & Calappa ocellata & 2 & 7.1 & 8 & 0.5 & 1.6 \\
\hline & Gonodactylidae & Neogonodactylus sp. & 1 & 3.6 & 4 & 1.2 & 0.5 \\
\hline & & Total Crustaceous & 3 & 10.7 & 12 & 1.7 & 2.1 \\
\hline \multicolumn{8}{|c|}{ Cephalopods } \\
\hline & Octopidae & Octopus vulgaris & 2 & 7.1 & 8 & 0.5 & 1.6 \\
\hline & Longinidae & Sepioteuthis sp. & 1 & 3.6 & 4 & 1.1 & 0.5 \\
\hline & & Total Cephalopods & 3 & 10.7 & 12 & 1.6 & 2.1 \\
\hline
\end{tabular}




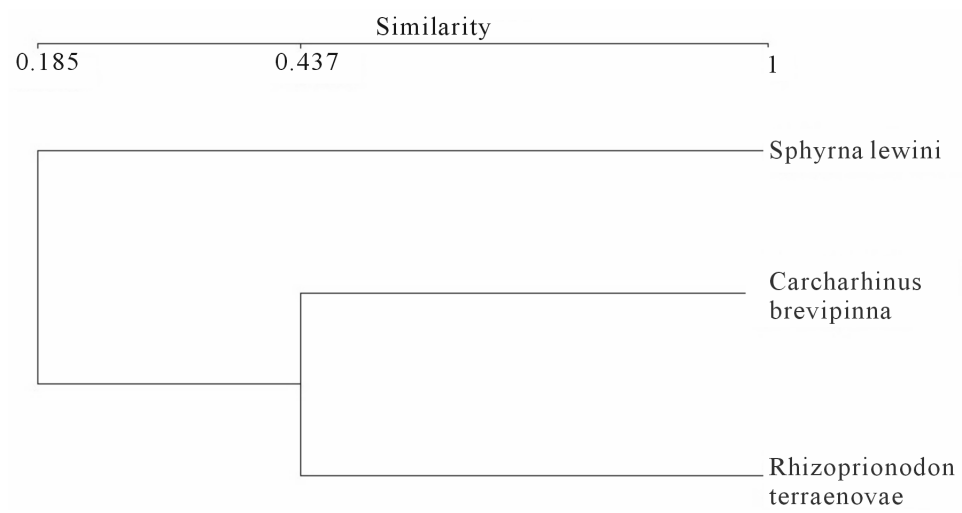

(a)

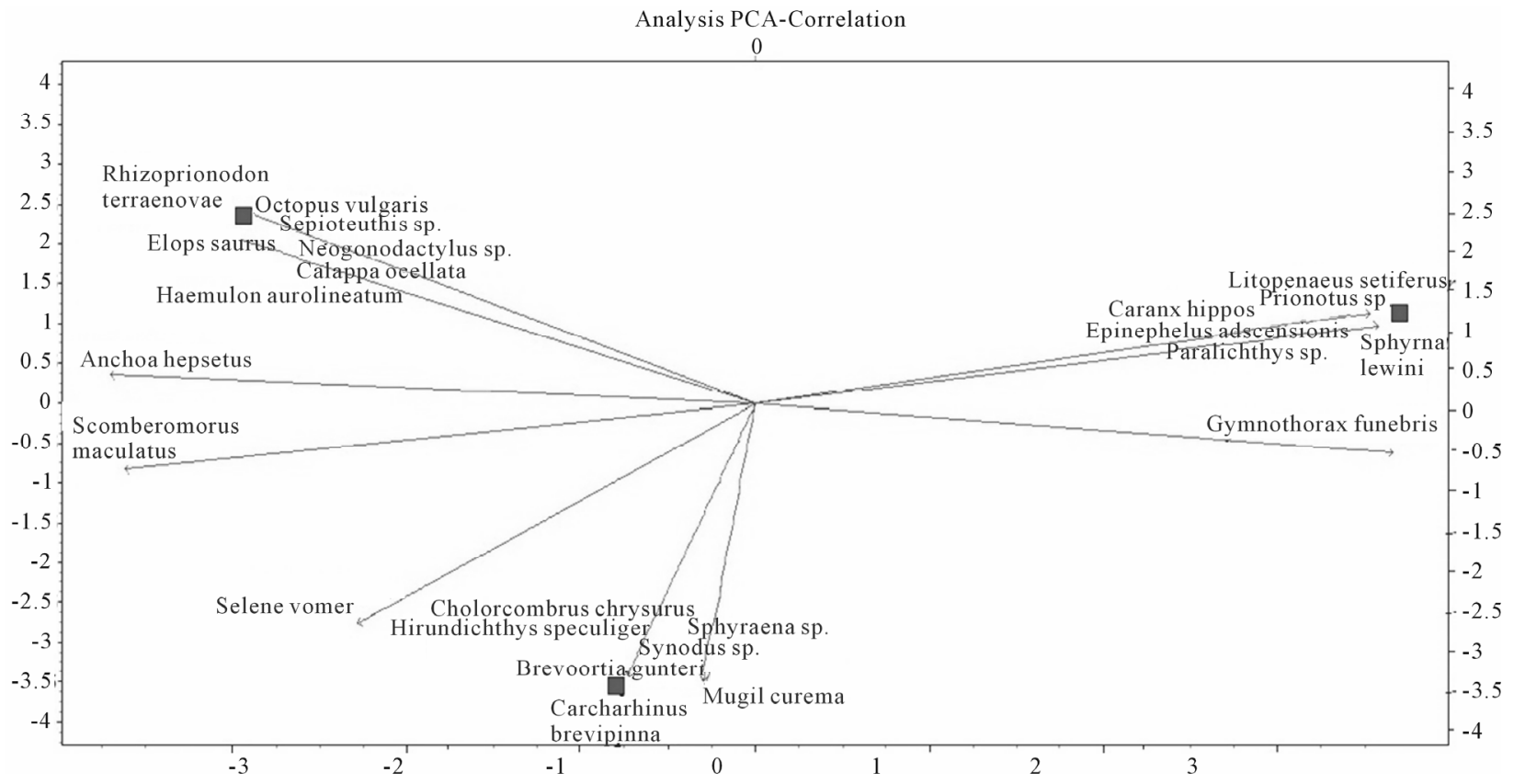

(b)

Figure 3. (a) Cluster of similarity and (b) PCA correlation for the trophic spectrum of the sharks species captured in the VRS.

shelf and the littoral areas, including bays, coastal lagoons and estuaries [1,14].

The artisanal fishery during the time of sampling, captured mostly immature shark, this was attributed to the fact that most species of sharks use these kinds of areas (reefs, bays and estuaries) for protection, feeding and development during their juvenile stages [20,28,29]. The areas of captured sharks suggest that sharks feed near to the cyclonic and anticyclonic eddies, the river discharges and to the swell system discharges near to the Port of Veracruz, owing to the abundance of small fishes and benthonic organisms. The VRS has been described as a high productivity area [27,30], making this area a seasonally or temporarily potential development site for some species of top predators such as sharks. It is necessary to pay special attention to the potential breeding areas and regions of local and seasonal abundance for the protection of sharks communities [31,32], since sharks have a continuous reduction in its population number around the world [6].

Due to the opportunistic feeding behavior of the shark species, two or more species of predators that share the same marine habitat may have a similar diet which will be determined by the availability of preys [22]. The sharks species sampled on this study feed on benthic and demersal preys with coastal and reef behaviors, which implies that these predators use the reef system to feed and for protection at least in one stage of its life cycle.

It is possible to observe that $S$. lewini feed more on benthic species. Its predator has been cataloged like an opportunistic predator around the world [14,29,33,34]. In the bay of Kane-Ohe, O'ahu, Hawaii, the juveniles of 
this species mostly feeds on benthic organisms specially from crustaceous [29]. This feeding behavior is probably due to the evolutionary adaptation of the species to hunt; however its diet changes on the adult stage, when they mainly feed of cephalopods [14,28,33,35].

It has been described that $C$. brevipinna is an opportunistic depredator that feeds essentially of teleosts but it can also feed of cephalopods [36]. This was confirmed in this study due to the notable presence of Octopus vulgaris in its diet (3.3\% IRI). In the bay of Apalachicola, Florida, the juveniles of this predator mainly feed of teleosts, where the Teleost represent the $96.7 \%$ IRI of its diet [37]. This characteristic has mainly been described for the Carcharhinus generous around the world [38-44].

Finally, $R$. terraenovae feed on a variety of benthic preys like crustaceous and cephalopods, but, with a clear tendency to feed on Teleost specially Haemulon aurolineatum $(72.9 \%$ IRI). The neonates of this predator in the bay of Apalachicola, Florida, usually to feed of shrimps, and the juveniles and adults usually feed of teleosts [37], the diet of this predator has been described like a generalist depredator with a tendency to feed on small Teleost fishes [45], similar to the once founded in this study.

This information helps to understand the adaptations of the top predators to their marine habitats and their interspecific and intraspecific interactions [22].

\section{Acknowledgements}

We want to thank to CONACyT with the project FOMIX 6757,2006 , as well as all those who with their help, cooperation and encouragement made possible the development of this investigation.

\section{REFERENCES}

[1] CONAPESCA-INP, "Plan de Acción Nacional para el Manejo y Conservación de Tiburones, Rayas y Especies Afines en México," Comisión Nacional de Acuacultura y Pesca e Instituto Nacional de la Pesca, Mazatlán, 2004.

[2] DOF, "Lunes 24 de Agosto," 1992.

[3] A. L. Lara-Domínguez, J. Franco-López, C. Bedia-Sánchez, L. G. Abarca-Arenas, S. Díaz-Ruiz, A. AguirreLeón, C. González-Gándara and M. Castillo-Rivera, "Diversidad de Peces en Los Ambientes Costeros y Plataforma Continental," Comisión Nacional Para el Conocimiento y Uso de la Biodiversidad (CONABIO), Vol. 2, No. 1, 2011, pp. 505-516.

[4] J. A. Musick, G. Burgess, G. Cailliet, M. Camhi and S. Fordham, "Management of Sharks and Their Relatives (Elasmobranchii)," Fisheries, Vol. 25, No. 3, 2000, pp. 913.

doi:10.1577/1548-8446(2000)025<0009:MOSATR >2.0.C $\underline{\mathrm{O} ; 2}$

[5] Diario Oficial de la Federación (DOF), "NORMA Oficial
Mexicana NOM-029-PESC-2006, Pesca Responsable de Tiburones y Rayas," Especificaciones Para su AproveChamiento, 2007.

[6] R. Bonfil, "Overview of World Elasmobranchs Fisheries, FAO," Fisheries Technical Paper, No. 341, 1994.

[7] Food and Agriculture Organization of the United Nations (FAO), "FAO Yearbook of Fishery Statistics: Summary Tables, Fish, Crustaceans, Mollusks, etc., Capture Production by Groups of Species," 2005.

[8] A. Myers, J. Baum, T. Shepherd, S. Powers and C. Peterson, "Cascading Effects of the Loss of Apex Predatory Sharks from a Coastal Ocean," Science, Vol. 315, No. 5820, 2007, pp. 1846-1850. doi:10.1126/science.1138657

[9] J. E. Lamilla, E. Acuña, M. Araya, I. Kong, M. Olivia, S. Hernández, J. C. Villarroel, F. Concha, R. Vogler, G. Pequeño and E. Mutschke, "Lineamientos Básicos Para Desarrollar el Plan de Acción Nacional de Conservación de Tiburones," Subsecretariat of Fisheries and Aquaculture, Vol. 1, No. 1, 2005, p. 223.

[10] J. J. Bizzarro, W. D. Smith, R. E. Hueter, J. Tyminski, J. F. Márquez, J. L. Farías Castillo-Géniz, G. M. Cailliet and C. J. Villavicencio-Garayzar, "El Estado Actual de Los Tiburones y Rayas Sujetos a Explotación Comercial en el Golfo de California: Una investigación Aplicada al Mejoramiento de su Manejo Pesquero y Conservación," 2007.

[11] S. Coello, "La Administración de Los Chondrichthyes en Ecuador," 2005.

[12] J. Estes, M. Tinker, T. Williams and D. Doak, "Killer Whale Predation on Sea Otters Linking Oceanic and Near Shore Ecosystems," Science, Vol. 282, No. 5388, 1998, pp. 473-476. doi:10.1126/science.282.5388.473

[13] E. Cortés, "Standardized Diet Compositions and Trophic Levels of Sharks," Canadian Journal of Fisheries and Aquatic Sciences, Vol. 56, No. 5, 1999, pp. 707-717.

[14] L. Compagno, M. Dando and S. Fowler, "A Field Guide to the Sharks of the World," Harper Collins Publisher. London, 2005.

[15] J. Castro, J. C. Woodley and R. Brudek, "A Preliminary Evaluation of the Status of Sharks Species," FAO, Roma. 1999.

[16] M. Camhi, E. Pikitch and E. Babcock, "Sharks of the Open Ocean: Biology, Fisheries and Conservation," Blackwell Science, Hoboken, 2008.

[17] J. Kitchell, T. Essington, C. Boggs, D. Schindler and C. Walters, "The Role of Sharks and Longline Fisheries in a Pelagic Ecosystem of the Central Pacific," Ecosystems, Vol. 5, No. 2, 2002. pp. 202-216. doi:10.1007/s10021-001-0065-5

[18] F. Galvan, H. Nienhuis and P. Klimley, "Seasonal Abundance and Feeding Habits of Sharks of the Lower Gulf of California, Mexico," Fish and Game, Vol. 75, No. 2, 1989. pp. 74-84.

[19] B. Wetherbee and E. Cortés, "Food Consumption and Feeding Habits," In: J. C. Carrier, J. Musick and M. Heithaus, Eds., Biology of Sharks and Their Relatives, CRC Press, Washington, 2004, pp. 225-246. doi:10.1201/9780203491317.ch8

[20] Heithaus, M, "Predator Prey Interactions," In: J. C. Carrier, J. Musick and M. Heithaus, Eds., Biology of Sharks 
and Their Relatives, CRC Press, Washington, 2004, pp. 487-521. doi:10.1201/9780203491317.ch17

[21] S. D. Gerking, "Feeding Ecology of the Fish," Academic Press, San Diego, 1994.

[22] J. C. Carrier, J. A. Musick and M. R. Heithaus, "Biology of Sharks and Their Relatives," CRC Press, Washington, 2004.

[23] T. Anislado and R. Mendoza, "Edad y Crecimiento del Tiburón Martillo Sphyrna lewini en el Pacífico Central de México," Ciencias Marinas, Vol. 27, No. 4, 2001, pp. 501-520.

[24] J. Shoou, L. Yih, L. Kwang, C. Che and L. Len, "Age, Growth, and Reproduction of the Spinner Shark, Carcharhinus brevipinna, in the Northeastern Waters of Taiwan," Zoological Studies, Vol. 44, No. 1, 2005, pp. 102110 .

[25] J. Loefer and G. Sedberry, "Life History of the Atlantic Sharpnose Shark (Rhizoprionodon terraenovae) (Richardson 1836) off the Southeastern United States," Fishery Bulletin, Vol. 101, No. 1, 2003, pp. 75-88.

[26] L. Pinkas, M. S. Oliphant and L. K. Iverson, "Food Habits of Albacore, Bluefin Tuna and Bonito in California Waters," Fishery Bulletin, Vol. 152, No. 1, 1971, p. 106.

[27] D. Salas-Monreal, D. A. Salas-de-León, M. A. MonrealGómez and M. L. Riverón-Enzástiga, "Current Rectification in a Tropical Coral Reef System," Coral Reefs, Vol. 28, No. 4, 2009, pp. 871-879. doi:10.1007/s00338-009-0521-9

[28] A. Bush and K. Holland, "Food Limitation in a Nursery Area: Estimates of Daily Ration in Juvenile Scalloped Hammerheads, Sphyrna lewini (Griffit \& Smith, 1834) in Kane'ohe Bay, O'ahu, Hawaii," Experimental Marine Biology and Ecology, Vol. 278, No. 2, 2002, pp. 157-178. doi:10.1016/S0022-0981(02)00332-5

[29] A. Bush, "Diet and Dial Feeding Periodicity of Juvenile Scalloped Hammerhead Sharks, Sphyrna lewini, in Kane' ohe Bay, O'ahu, Hawaii," Environmental Biology of Fishes, Vol. 67, No. 1, 2003, pp. 1-11. doi:10.1023/A:1024438706814

[30] J. J. Salas-Pérez and A. Granados-Barba, "Oceanographic Characterization of the Veracruz Reefs System," Atmósfera, Vol. 21, No. 3, 2008, pp. 281-301.

[31] S. P. Applegate, F. Soltelo-Macias and L. Espinosa-Arrubarrena, "An Overview of Mexican Shark Fisheries, with Suggestions for Shark Conservation in Mexico," In: S. Branstetter, Ed., Conservation Biology of Sharks, NOAA Technical Report NMFS, 1993, pp. 31-37.

[32] J. L. Castillo-Géniz, J. F. Márquez-Farías, M. C. Rodríguez de la Cruz, E. Cortés and A. Cid del Prado, "The Mexican Artisanal Fishery in the Gulf of Mexico: Towards a Regulated Fishery," Marine and Freshwater Research, Vol. 49, No. 7, 1998, pp. 611-620. doi:10.1071/MF97120

[33] C. Estupiñan-Montaño, L. G. Cedeño-Figueroa and F. Galvan-Magaña, "Hábitos Alimentarios de la Cornuda Común Sphyrna lewini (Griffit \& Smith, 1834) (Chondrichthyes) en el Pacifico Ecuatoriano," Revista de Biología Marina y Oceanografía, Vol. 44, No. 2, 2009, pp. 379-386.
[34] Y. Torres-Rojas, A. Hernández-Herrera, F. Galván Magaña and V. G. Alatorre-Ramírez, "Stomach Contain Analysis of Juvenile, Scalloped Hammerhed Shark Sphyrna lewini Captured off the Coast of Mazatlan, Mexico," Aquatic Ecology, Vol. 44, No. 1, 2010, pp. 301-308. doi:10.1007/s10452-009-9245-8

[35] G. Cliff, "Sharks Caught in the Protective Gill Nets off Kwazulu-Natal, South Africa. The Great Hammerhead Shark (Sphyrna mokarran) (Ruppell)," South African Journal of Marine Science, Vol. 15, No. 1, 1995, pp. 105114. doi:10.2989/025776195784156331

[36] L. J. Compagno, "FAO Species Catalogue, Sharks of the World. An Annotated and Illustrated Catalogue of Shark Species Known to Date. Part 2. Carcharhiniformes," FAO Species Catalogue, Vol. 4, No. 125, 1984, pp. 251655.

[37] D. M. Bethea, J. A. Buckel and J. K. Carlson, "Foraging Ecology of the Early Life Stages of Four Sympatric Shark Species," Marine Ecology Progress Series, Vol. 268, No. 1, 2004, pp. 245-264. doi:10.3354/meps268245

[38] A. J. Bass, J. D. D'Aubrey and N. Kistnasamy, "Sharks of the East Coast of Southern Africa I. The genus Carcharhinus (Carcharhinidae)," Investigational Report, Vol. 1, No. 33, 1973, pp. 1-168.

[39] J. D. Stevens and P. D. Wiley, "Biology of Two Commercially Important Carcharhinid Sharks from Northern Australia," Australian Journal of Marine and Freshwater Research, Vol. 37, No. 6, 1986, pp. 671-688. doi:10.1071/MF9860671

[40] J. D. Stevens and K. J. McLoughlin, "Distribution, Size, and Sex Composition, Reproductive Biology and Diet of Sharks from Northern Australia," Australian Journal of Marine and Freshwater Research, Vol. 42, No. 2, 1991, pp. 129-146. doi:10.1071/MF9910151

[41] G. Cliff and S. F. J. Dudley, "Sharks Caught in the Protective Gill Nets of Naal, South Africa. The Copper Shark (Carcharhinus plumbeus) (Nardo)," South African Journal of Marine Science, Vol. 7, No. 1, 1988, pp. 255-265. doi: $10.2989 / 025776191784287817$

[42] J. P. Salini, S. J. M. Blaber and D. T. Brewer, "Diets of Sharks from Estuaries and Adjacent Waters of the Northeastern Gulf of Carpentaria, Australia," Australian Journal of Marine and Freshwater Research, Vol. 43, No. 1, 1992, pp. 87-96. doi:10.1071/MF9920087

[43] J. I. Castro, "The Shark Nursery of Bulls Bay, South Carolina, with a Review of the Shark Nurseries of the Southeastern Coast of the United States," Enviromental Biology of Fishes, Vol. 38, No. 1-3, 1993, pp. 37-48. doi:10.1007/BF00842902

[44] S. F. Dudley and G. Cliff, "Sharks Caught in the Protective Gill Nets of Natal, South Africa. The Blactip Shark (Carcharhinus limbatus) (Valenciennes)," South African Journal of Marine Science, Vol. 13, No. 1, 1993, pp. 237-254. doi:10.2989/025776193784287356

[45] K. Barry, "Feeding Habits of Blacktip Sharks, Carcharhinus limbatus, and Atlantic Sharpnose Sharks, Rhizoprionodon terraenovae, in Louisiana Coastal Waters," Dissertation, University and Agricultural and Mechanical College, Louisiana, 2002. 